\title{
Jannaschia pohangensis sp. nov., isolated from seashore sand in Korea
}

\author{
Byung-Yong Kim, ${ }^{1}$ Seung-Hee Yoo, ${ }^{1}$ Hang-Yeon Weon, ${ }^{2}$ \\ Young-Ah Jeon, ${ }^{1}$ Seung-Beom Hong, ${ }^{1}$ Seung-Joo Go, ${ }^{1}$ \\ Erko Stackebrandt ${ }^{3}$ and Soon-Wo Kwon ${ }^{1}$
}

Correspondence

Soon-Wo Kwon

swkwon@rda.go.kr
${ }^{1}$ KACC - Korean Agricultural Culture Collection, Microbial Genetics Division, National Institute of Agricultural Biotechnology, Rural Development Administration, Suwon 441-707, Republic of Korea

${ }^{2}$ Applied Microbiology Division, National Institute of Agricultural Science and Technology, Rural Development Administration, Suwon 441-707, Republic of Korea

${ }^{3} \mathrm{DSMZ}$ - Deutsche Sammlung von Mikroorganismen und Zellkulturen GmbH, Inhoffenstraße 7b, D-38124 Braunschweig, Germany

\begin{abstract}
A Gram-negative, aerobic bacterium, $\mathrm{H} 1-\mathrm{M}^{\top}$, was isolated from seashore sand in Korea and then characterized using a polyphasic approach. Cells were short rods $(0.7-1.0 \times 1.5-2.0 \mu \mathrm{m})$ and were motile (each cell having at least one flagellum). Colonies were light-brown, non-pigmented, circular and convex with clear margins. Growth of the strain was observed at $5-35{ }^{\circ} \mathrm{C}$,

$\mathrm{pH}$ 6.0-9.0 and $\mathrm{NaCl}$ concentrations up to $8.4 \%(\mathrm{w} / \mathrm{v})$. Phylogenetic analysis of the 16S rRNA gene sequence revealed a clear affiliation between the novel strain and members of the genus Jannaschia. The sequence similarities between $\mathrm{H}_{1}-\mathrm{M}^{\top}{ }^{\top}$ and type strains of the genus Jannaschia ranged from 97.0 to $97.8 \%$. However, DNA-DNA hybridizations between the isolate and type strains of other related species produced low values (21-38\%). The major isoprenoid quinone was Q-10 and the predominant cellular fatty acids were $18: 1 \omega 7 c(68.2 \%)$ and $18: 0(10.5 \%)$. The $\mathrm{G}+\mathrm{C}$ content of the DNA was $63.6 \mathrm{~mol} \%$. On the basis of physiological, biochemical and chemotaxonomic traits and data from the comparative 16S rRNA sequence analysis, strain $\mathrm{H} 1-\mathrm{M}^{\top}$ represents a novel species of the genus Jannaschia, for which the name Jannaschia pohangensis sp. nov. is proposed. The type strain is $\mathrm{H} 1-\mathrm{M}^{\top}\left(=\mathrm{KACC}^{\top 1609^{\top}}=\mathrm{DSM} 19073^{\top}\right)$.
\end{abstract}

The genus Jannaschia was proposed for Gram-negative, strictly aerobic, non-fermentative heterotrophs (WagnerDöbler et al., 2003). This genus is a member of the Alphaproteobacteria. At the time of writing, there are four accepted species in the genus Jannaschia: Jannaschia helgolandensis, J. rubra, J. seosinensis and J. donghaensis (Wagner-Döbler et al., 2003; Macián et al., 2005; Choi et al., 2006; Yoon et al., 2007). The type species, J. helgolandensis, contains Q-10 as the major respiratory quinone and $18: 1 \omega 7 c$ as the major fatty acid. Recently, Jannaschia cystaugens (Adachi et al., 2004) was transferred to the genus Thalassobacter as a synonym of Thalassobacter stenotrophicus (Pujalte et al., 2005).

\section{Abbreviation: $E C L$, equivalent chain length.}

The GenBank/EMBL/DDBJ accession number for the $16 \mathrm{~S}$ rRNA gene sequence of strain $\mathrm{H}_{1-\mathrm{M}^{\top}}$ is DQ643999.

A transmission electron micrograph of a cell of strain $\mathrm{H} 1-\mathrm{M}^{\top}$ and a table showing the cellular fatty acid compositions of strain $\mathrm{H} 1-\mathrm{M} 8^{\top}$ and type strains of Jannaschia species are available as supplementary material with the online version of this paper.
Strain $\mathrm{H} 1-\mathrm{M}^{\mathrm{T}}$ was isolated from seashore sand, using marine agar 2216 (MA; Difco). The seashore sand sample was collected from Homi Cape in Pohang, Republic of Korea. Serially diluted samples were spread on MA and incubated at $28{ }^{\circ} \mathrm{C}$ for 5 days. The strain did not grow on nutrient agar (Difco), R2A agar (Difco), trypticase soy agar (Difco) or MacConkey agar (Difco). The cell morphology was studied using transmission electron microscopy (model 912AB; LEO) and phase-contrast microscopy (Axio; Zeiss), with cells grown for 3 days at $28{ }^{\circ} \mathrm{C}$ on MA. Gram staining, catalase and oxidase activity and hydrolysis of casein, DNA, starch and Tween 80 were investigated according to the methods of Smibert \& Krieg (1994). The temperature range for growth was tested on MA from 5 to $40{ }^{\circ} \mathrm{C}$, in increments of $5{ }^{\circ} \mathrm{C}$. The $\mathrm{pH}$ range for growth was determined in the range $\mathrm{pH} 5-10$, in increments of $1 \mathrm{pH}$ unit, in marine broth buffered with citrate/phosphate buffer or Tris/ $\mathrm{HCl}$ (Breznak \& Costilow, 1994). Halotolerance was tested at $28{ }^{\circ} \mathrm{C}$ for 10 days in tryptic soy broth (Difco) containing $0-20 \%(\mathrm{w} / \mathrm{v}) \mathrm{NaCl}$ and in marine broth (Difco) supplemented with $0-10 \%$ $\mathrm{NaCl}(\mathrm{w} / \mathrm{v})$. Anaerobic growth was also tested on MA 
incubated in an anaerobic jar (BBL). Hydrolysis of alginic acid $(0.5 \%$, w/v), CM-cellulose (Sigma) $(0.1 \%)$, chitin $(1 \%, \mathrm{w} / \mathrm{v})$, pectin $(0.5 \%, \mathrm{w} / \mathrm{v})$ and tyrosine $(0.5 \%, \mathrm{w} / \mathrm{v})$ was also tested on MA. Carbon utilization was tested on basal medium agar [Tris/HCl, $50 \mathrm{mM}, \mathrm{pH} 7.5 ; \mathrm{NH}_{4} \mathrm{Cl}$, $190 \mathrm{mM} ; \quad \mathrm{K}_{2} \mathrm{HPO}_{4} .3 \mathrm{H}_{2} \mathrm{O}, \quad 0.33 \mathrm{mM} ; \quad \mathrm{FeSO}_{4} .7 \mathrm{H}_{2} \mathrm{O}$, $0.1 \mathrm{mM}$ and $1.5 \%$ Bacto agar (Difco) in half-strength artificial seawater (Baumann \& Baumann, 1981)] containing $0.2 \%$ carbon source. The basal medium agar was supplemented with $0.01 \%$ yeast extract. Tests in the commercial systems API 20NE and API ZYM (bioMérieux) were generally performed according to the manufacturer's instructions.

Cells of strain $\mathrm{H} 1-\mathrm{M} 8^{\mathrm{T}}$ were aerobic, Gram-negative, short rods, each having one or more polar flagella (Supplementary Fig. S1, available in IJSEM Online). The strain was positive for oxidase and catalase activities. It did not grow anaerobically. Strain $\mathrm{H} 1-\mathrm{M} 8^{\mathrm{T}}$ could be differentiated from its closest phylogenetic relative, J. helgolandensis DSM $14858^{\mathrm{T}}$, on the basis of motility, the hydrolysis of gelatin and aesculin, the temperature range for growth and assimilation patterns for several carbon sources (see Table 1 and the species description).

The 16S rRNA gene was analysed as described by Kwon et al. (2003). 16S rRNA gene sequences were aligned using CLUSTAL W software (Thompson et al., 1994). Nucleotide similarity values were calculated from the alignment. Phylogenetic trees for the datasets were inferred using the neighbour-joining (Saitou \& Nei, 1987) and maximumparsimony (Fitch, 1971) methods with MEGA, version 3.0 (Kumar et al., 2004). The stability of relationships was assessed by performing bootstrap analyses based on 1000 resamplings. Strain $\mathrm{H} 1-\mathrm{M} 8{ }^{\mathrm{T}}$ showed the highest sequence similarities (97.0-97.8\%) with respect to the type strains of J. helgolandensis $(97.8 \%)$, J. rubra $(97.3 \%)$, J. seosinensis $(97.3 \%)$ and $J$. donghaensis $(97.0 \%)$. Lower sequence similarities $(<96.0 \%)$ were found with respect to described species from other genera. Furthermore, the four Jannaschia type strains and $\mathrm{H} 1-\mathrm{M} 8^{\mathrm{T}}$ formed a compact cluster that is most closely related to Thalassobacter

Table 1. Phenotypic characteristics that serve to differentiate $\mathrm{H} 1-\mathrm{M} 8^{\top}$ from type strains of Jannaschia species

Strains: 1, H1-M8 ${ }^{\mathrm{T}}$; 2, J. helgolandensis DSM $14858^{\mathrm{T}}$ (data from Wagner-Döbler et al., 2003); 3, J. rubra DSM 16279 ${ }^{\mathrm{T}}$ (Macián et al., 2005); 4, J. seosinensis CL-SP26 ${ }^{\mathrm{T}}$ (Choi et al., 2006); 5, J. donghaensis DSW-17 ${ }^{\mathrm{T}}$ (Yoon et al., 2007). API 20NE data were obtained from Choi et al. (2006), Yoon et al. (2007) and this study. Utilization data for all strains except DSW $-17^{\mathrm{T}}$ were obtained from this study. None of the strains utilized cellobiose, maltose, sucrose or trehalose. + , Positive; $(+)$, weakly positive; -, negative; NA, data not available.

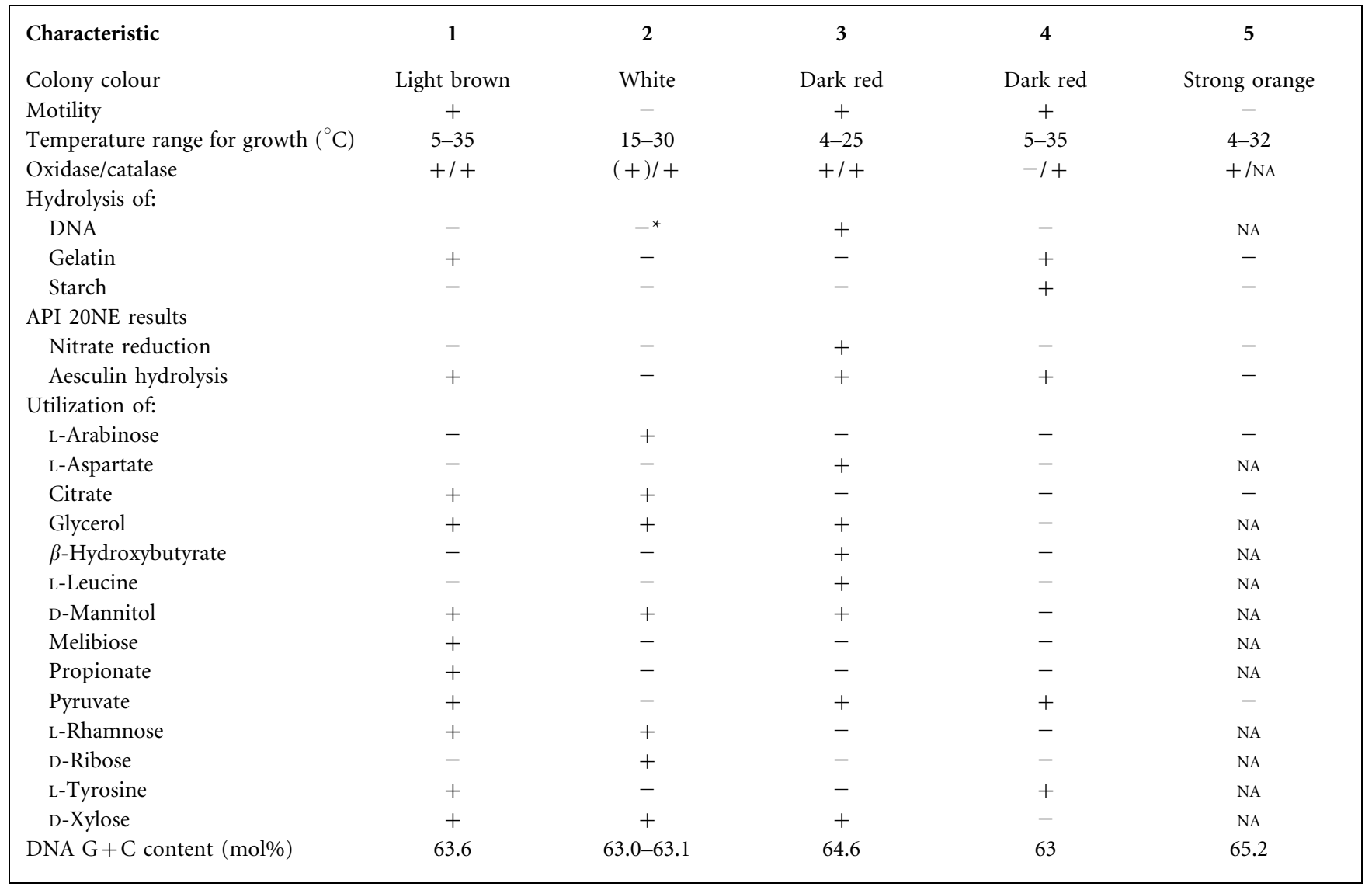

${ }^{\star}$ Data from Macián et al. (2005). 


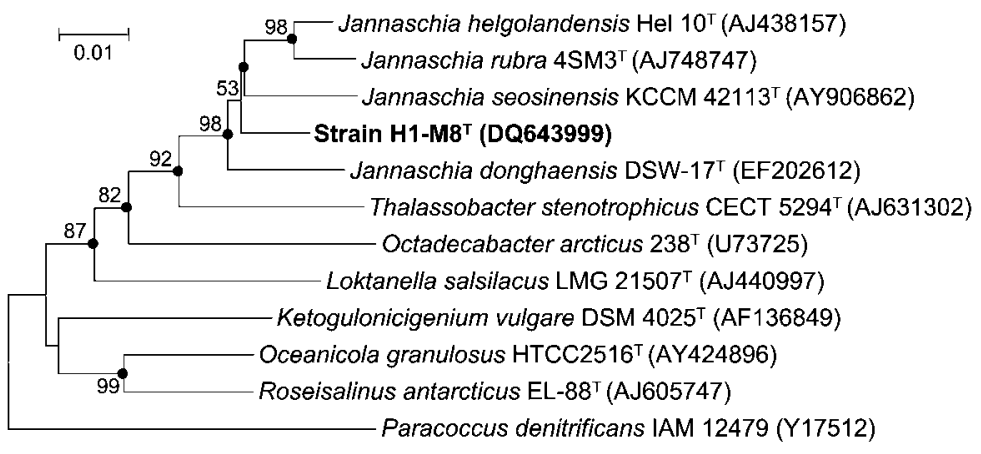

Fig. 1. Neighbour-joining phylogenetic tree, based on 16S rRNA sequences, showing the positions of strain $\mathrm{H} 1-\mathrm{M}^{\top}$ and its relatives. Numbers at nodes indicate levels of bootstrap support (based on analysis of 1000 resampled datasets); bootstrap percentages below $50 \%$ are not shown. Filled circles indicate that the corresponding nodes were also recovered in the tree generated with the maximum-parsimony algorithm. Bar, 0.01 nucleotide substitutions per site.

stenotrophicus (98\% bootstrap support) (Fig. 1). The tree constructed using maximum parsimony also supported the affiliation of strain $\mathrm{H} 1-\mathrm{M} 8^{\mathrm{T}}$ with the genus Jannaschia.

For quantitative analysis of the whole-cell fatty acids of H1$\mathrm{M}^{\mathrm{T}}$, the strain was cultivated on MA at $28{ }^{\circ} \mathrm{C}$ for 4 days. The preparation and analysis of the fatty acid methyl esters were performed according to the standard protocol of the MIDI/Hewlett Packard Microbial Identification System (Sasser, 1990). The fatty acid pattern of strain $\mathrm{H} 1-\mathrm{M}^{\mathrm{T}}{ }^{\mathrm{T}}$ was largely similar to those of Jannaschia species. Strain H1$\mathrm{M}^{\mathrm{T}}$ contained $18: 1 \omega 7 c(68.2 \%)$ as the predominant fatty acid, which is a characteristic shared by the species of the genus Jannaschia. However, $\mathrm{H} 1-\mathrm{M} 8^{\mathrm{T}}$ could be unique in possessing a moderate amount $(8.0 \%)$ of $18: 1 \omega 7 c 11$ methyl and lacking 16:0, 19:0, 19:0 10-methyl, 19:0 $08 c$ cyclo and summed feature $2(14: 03-\mathrm{OH} / 16: 1$ iso). The fatty acid profiles of the isolate and the type strains of Jannaschia species are detailed in Supplementary Table S1.

Isoprenoid quinones were extracted from dry cell mass and analysed by HPLC (Minnikin et al., 1984; Groth et al., 1996); the DNA G + C content (mol\%) was also measured by HPLC (Mesbah et al., 1989). The predominant isoprenoid quinone in strain $\mathrm{H} 1-\mathrm{M} 8^{\mathrm{T}}$ was $\mathrm{Q}-10$ and the $\mathrm{G}+\mathrm{C}$ content of the genomic DNA of strain $\mathrm{H} 1-\mathrm{M}^{\mathrm{T}}{ }^{\mathrm{T}}$ was $63.6 \mathrm{~mol} \%$.

DNA-DNA hybridization experiments were performed with strain $\mathrm{H} 1-\mathrm{M} 8^{\mathrm{T}}$ and type strains of three Jannaschia species by using the filter hybridization method described by Seldin \& Dubnau (1985). Probe labelling was conducted by using the non-radioactive DIG-High Prime system (Roche) and hybridized DNA was visualized using the DIG luminescent detection kit (Roche). DNA-DNA relatedness was quantified by using a densitometer (Bio-Rad). Strain $\mathrm{H} 1-\mathrm{M}^{\mathrm{T}}$ showed low values for hybridization with $\mathrm{J}$. helgolandensis DSM $14858^{\mathrm{T}}$ (21\%), J. rubra DSM $16279^{\mathrm{T}}$ $(38 \%)$ and J. seosinensis KCCM $42114^{\mathrm{T}}(24 \%)$. These values are below the $70 \%$ threshold suggested for species delineation (Stackebrandt \& Goebel, 1994), indicating that strain $\mathrm{H} 1-\mathrm{M}^{\mathrm{T}}$ is separate at the species level.

In conclusion, the $16 \mathrm{~S}$ rRNA sequence, physiological characteristics and fatty acid profile of strain $\mathrm{H} 1-\mathrm{M}^{\mathrm{T}}$ differed from those of its phylogenetic neighbours.
Furthermore, the low levels of DNA-DNA relatedness supported the novelty of the isolate. On the basis of the data presented, therefore, strain $\mathrm{H} 1-\mathrm{M} 8^{\mathrm{T}}$ represents a novel species of the genus Jannaschia, for which the name Jannaschia pohangensis sp. nov. is proposed.

\section{Description of Jannaschia pohangensis sp. nov.}

Jannaschia pohangensis (po.hang.en'sis. N.L. fem. adj. pohangensis referring to Pohang Region in the Republic of Korea, where the type strain was found).

Cells are Gram-negative, strictly aerobic rods, approximately $0.7-1.0 \mu \mathrm{m}$ wide and $1.5-2.0 \mu \mathrm{m}$ long. Motile (one or more polar flagella). Colonies are light brown, non-pigmented, circular and convex with clear margins. Grows at $5-35{ }^{\circ} \mathrm{C}$ (optimally at $30^{\circ} \mathrm{C}$ ) and $\mathrm{pH} \mathrm{6-9} \mathrm{(optimally} \mathrm{at} \mathrm{pH}$ 7). Growth occurs at $\mathrm{NaCl}$ concentrations up to $8.4 \%$. No growth occurs in tryptic soy broth containing $\mathrm{NaCl}$ as the only salt. Does not grow under anaerobic conditions. Catalase- and oxidase-positive. Hydrolyses tyrosine but not alginic acid, CM-cellulose, casein, chitin, DNA, pectin, starch or Tween 80 . Utilizes citrate, D-fructose, D-galactose, D-glucose, L-glutamate, glycerol, D-mannitol, D-mannose, melibiose, propionate, pyruvate, L-rhamnose, L-serine, Ltyrosine and D-xylose, but not L-alanine, L-arabinose, Laspartate, cellobiose, glycine, L-histidine, $\beta$-hydroxybutyrate, lactose, L-leucine, maltose, D-ribose, sucrose, L-threonine or trehalose. Positive for $\beta$-galactosidase and for hydrolysis of gelatin, urea and aesculin, but negative for nitrate reduction, indole production, arginine dihydrolase and acid production from glucose (API 20NE test strips). Positive for alkaline phosphatase, esterase ( $\mathrm{C} 4$ and $\mathrm{C} 8)$, leucine arylamidase, acid phosphatase, naphthol-AS-BI-phosphohydrolase and $\beta$-galactosidase, but negative for lipase (C14), valine arylamidase, cystine arylamidase, trypsin, $\alpha$-chymotrypsin, $\alpha$-galactosidase, $\beta$-glucuronidase, $\alpha$-glucosidase, $\beta$ glucosidase, $N$-acetyl- $\beta$-glucosaminidase, $\alpha$-mannosidase and $\alpha$-fucosidase (API ZYM test strips). The fatty acids are $18: 1 \omega 7 c(68.2 \%), 18: 0 \quad(10.5 \%), 18: 1 \omega 7 c$ 11-methyl $(8.0 \%), 10: 03-\mathrm{OH}(4.4 \%)$, an unknown fatty acid with an equivalent chain length (ECL) of $11.799(3.9 \%)$ and summed feature 7 [unknown (ECL 18.846)/19: $1 \omega 6 c ; 2.8 \%$ ]. The major quinone is $\mathrm{Q}-10$. The DNA G $+\mathrm{C}$ content of the type strain is $63.6 \mathrm{~mol} \%$ (HPLC). 
The type strain, H1-M8 ${ }^{\mathrm{T}} \quad$ (=KACC $11609^{\mathrm{T}}=\mathrm{DSM}$ $19073^{\mathrm{T}}$ ), was isolated from seashore sand in Pohang, Republic of Korea.

\section{Acknowledgements}

This study was supported by the National Institute of Agricultural Biotechnology (grant no. 06-4-11-19-1), Rural Development Administration, Republic of Korea.

\section{References}

Adachi, M., Kanno, T., Okamoto, R., Shinozaki, A., Fujikawa-Adachi, K. \& Nishijima, T. (2004). Jannaschia cystaugens sp. nov., an Alexandrium (Dinophyceae) cyst formation-promoting bacterium from Hiroshima Bay, Japan. Int J Syst Evol Microbiol 54, 1687-1692.

Baumann, P. \& Baumann, L. (1981). The marine Gram-negative eubacteria: genera Photobacterium, Beneckea, Alteromonas, Pseudomonas, and Alcaligenes. In The Prokaryotes, pp. 1302-1330. Edited by M. P. Starr, H. Stolp, H. G. Trüper, A. Balows \& H. G. Schlegel. Berlin: Springer.

Breznak, J. A. \& Costilow, R. N. (1994). Physicochemical factors in growth. In Methods for General and Molecular Bacteriology, pp. 137154. Edited by P. Gerhardt, R. G. E. Murray, W. A. Wood \& N. R. Krieg. Washington, DC: American Society for Microbiology.

Choi, D. H., Yi, H., Chun, J. \& Cho, B. C. (2006). Jannaschia seosinensis sp. nov., isolated from hypersaline water of a solar saltern in Korea. Int J Syst Evol Microbiol 56, 45-49.

Fitch, W. M. (1971). Toward defining the course of evolution: minimum change for a specific tree topology. Syst Zool 20, 406-416.

Groth, I., Schumann, P., Weiss, N., Martin, K. \& Rainey, F. A. (1996). Agrococcus jenensis gen. nov., sp. nov., a new genus of actinomycetes with diaminobutyric acid in the cell wall. Int J Syst Bacteriol 46, 234-239.

Kumar, S., Tamura, K. \& Nei, M. (2004). MEGA3: integrated software for molecular evolutionary genetics analysis and sequence alignment. Brief Bioinform 5, 150-163.

Kwon, S. W., Kim, J. S., Park, I. C., Yoon, S. H., Park, D. H., Lim, C. K. \& Go, S. J. (2003). Pseudomonas koreensis sp. nov., Pseudomonas umsongensis sp. nov. and Pseudomonas jinjuensis sp. nov., novel species from farm soils in Korea. Int J Syst Evol Microbiol 53, 21-27.
Macián, M. C., Arahal, D. R., Garay, E., Ludwig, W., Schleifer, K. H. \& Pujalte, M. J. (2005). Jannaschia rubra sp. nov., a red-pigmented bacterium isolated from sea water. Int J Syst Evol Microbiol 55, 649-653.

Mesbah, M., Premachandran, U. \& Whitman, W. B. (1989). Precise measurement of the $\mathrm{G}+\mathrm{C}$ content of deoxyribonucleic acid by highperformance liquid chromatography. Int J Syst Bacteriol 39, 159-167.

Minnikin, D. E., O’Donnell, A. G., Goodfellow, M., Alderson, G., Athalye, M., Schaal, A. \& Parlett, J. H. (1984). An integrated procedure for the extraction of bacterial isoprenoid quinones and polar lipids. J Microbiol Methods 2, 233-241.

Pujalte, M. J., Macián, M. C., Arahal, D. R. \& Garay, E. (2005). Thalassobacter stenotrophicus Macián et al. 2005 is a later synonym of Jannaschia cystaugens Adachi et al. 2004, with emended description of the genus Thalassobacter. Int J Syst Evol Microbiol 55, 1959-1963.

Saitou, N. \& Nei, M. (1987). The neighbor-joining method: a new method for reconstructing phylogenetic trees. Mol Biol Evol 4, 406-425.

Sasser, M. (1990). Identification of bacteria by gas chromatography of cellular fatty acids. USFCC Newsl 20, 16.

Seldin, L. \& Dubnau, D. (1985). Deoxyribonucleic acid homology among Bacillus polymyxa, Bacillus macerans, Bacillus azotofixans, and other nitrogen-fixing Bacillus strains. Int J Syst Bacteriol 35, 151-154.

Smibert, R. M. \& Krieg, N. R. (1994). Phenotypic characterization. In Methods for General and Molecular Bacteriology, pp. 607-654. Edited by P. Gerhardt, R. G. E. Murray, W. A. Wood \& N. R. Krieg. Washington, DC: American Society for Microbiology.

Stackebrandt, E. \& Goebel, B. M. (1994). Taxonomic note: a place for DNA-DNA reassociation and $16 \mathrm{~S}$ rRNA sequence analysis in the present species definition in bacteriology. Int J Syst Bacteriol 44, 846-849.

Thompson, J. D., Higgins, D. G. \& Gibson, T. J. (1994). CLUSTAL W: improving the sensitivity of progressive multiple sequence alignment through sequence weighting, position-specific gap penalties and weight matrix choice. Nucleic Acids Res 22, 4673-4680.

Wagner-Döbler, I., Rheims, H., Felske, A., Pukall, R. \& Tindall, B. J. (2003). Jannaschia helgolandensis gen. nov., sp. nov., a novel abundant member of the marine Roseobacter clade from the North Sea. Int J Syst Evol Microbiol 53, 731-738.

Yoon, J.-H., Kang, S.-J., Park, S. \& Oh, T.-K. (2007). Jannaschia donghaensis sp. nov., isolated from seawater of the East Sea, Korea. Int J Syst Evol Microbiol 57, 2132-2136. 